\title{
The influence of oxygen and methane on nitrogen fixation in subarctic Sphagnum mosses
}

\author{
Martine A. R. Kox ${ }^{1 *}$ (D), Sanni L. Aalto ${ }^{2,3}$, Timo Penttilä ${ }^{4}$, Katharina F. Ettwig ${ }^{1}$, Mike S. M. Jetten ${ }^{1}$ \\ and Maartje A. H. J. van Kessel ${ }^{1}$
}

\begin{abstract}
Biological nitrogen fixation is an important source of bioavailable nitrogen in Sphagnum dominated peatlands. Sphagnum mosses harbor a diverse microbiome including nitrogen-fixing and methane $\left(\mathrm{CH}_{4}\right)$ oxidizing bacteria. The inhibitory effect of oxygen on microbial nitrogen fixation is documented for many bacteria. However, the role of nitrogenfixing methanotrophs in nitrogen supply to Sphagnum peat mosses is not well explored. Here, we investigated the role of both oxygen and methane on nitrogen fixation in subarctic Sphagnum peat mosses. Five species of Sphagnum mosses were sampled from two mesotrophic and three oligotrophic sites within the Lakkasuo peatland in Orivesi, central Finland. Mosses were incubated under either ambient or low oxygen conditions in the presence or absence of methane. Stable isotope activity assays revealed considerable nitrogen-fixing and methane-assimilating rates at all sites $\left(1.4 \pm 0.2 \mu \mathrm{mol}{ }^{15} \mathrm{~N}-\mathrm{N}_{2} \mathrm{~g}^{-1} \mathrm{DW}\right.$ day ${ }^{-1}$ and $12.0 \pm 1.1 \mu \mathrm{mol}{ }^{13} \mathrm{C}^{-} \mathrm{CH}_{4} \mathrm{~g}^{-1} \mathrm{DW}$ day ${ }^{-1}$, respectively). Addition of methane did not stimulate incorporation of ${ }^{15} \mathrm{~N}$-nitrogen into biomass, whereas oxygen depletion increased the activity of the nitrogen-fixing community. Analysis of the $16 \mathrm{~S}$ rRNA genes at the bacterial community level showed a very diverse microbiome that was dominated by Alphaproteobacteria in all sites. Bona fide methane-oxidizing taxa were not very abundant (relative abundance less than $0.1 \%$ ). Based on our results we conclude that methanotrophs did not contribute significantly to nitrogen fixation in the investigated peatlands.
\end{abstract}

Keywords: Diazotrophy, Methane oxidation, Oxygen, Peatland, Sphagnum moss, 16S rRNA amplicon sequencing

\section{Introduction}

Biological nitrogen $\left(\mathrm{N}_{2}\right)$ fixation is of great importance to the Earth's biosphere as it is the major natural process to replenish biologically available nitrogen. In nutrient-limited ecosystems, the better competitors are often those that find alternative ways to gain their required nutrients, i.e. by engaging in a symbiosis with other organisms (van der Heijden et al. 2008). Peatlands are nutrientlimited ecosystems that have been studied intensively due to their significant role in the global carbon (C) cycle. Approximately $1 / 3$ of the global terrestrial carbon is stored as dead organic matter in peatlands (Gorham

\footnotetext{
*Correspondence: m.kox@science.ru.nl

1 Department of Microbiology, Radboud University, Nijmegen, The Netherlands

Full list of author information is available at the end of the article
}

1991). In Sphagnum-dominated peatlands, Sphagnum mosses are the ecosystem engineers. They outcompete vascular plant species in various ways (Malmer et al. 2003), but mainly by creating and maintaining acidic ( $\mathrm{pH}$ 3-5) and waterlogged conditions. In addition, their own biomass is difficult to degrade, which contributes to the slow decomposition and consequential accumulation of dead organic matter (Clymo 1963, 1964; van Breemen 1995). Peat fens that are mesotrophic or oligotrophic receive $\mathrm{N}$ from atmospheric deposition and ground water inflow. Compared to mesotrophic fens, oligotrophic fens receive less nutrients, leading to nutrient limitation and lower productivity (Larmola et al. 2014). In both systems, Sphagnum mosses minimize nutrient availability for vascular plants by rapid and efficient nutrient uptake (Fritz et al. 2014). 
In these nutrient-limited peatlands, Sphagnum circumvents $\mathrm{N}$-limitation by engaging in a relationship with $\mathrm{N}_{2}$ fixing microorganisms (diazotrophs). Diazotrophs convert atmospheric $\mathrm{N}_{2}$ to ammonia $\left(\mathrm{NH}_{3}\right)$. This is a costly process (16 ATP per $\mathrm{N}_{2}$ molecule) catalyzed by an oxygen $\left(\mathrm{O}_{2}\right)$ sensitive nitrogenase enzyme (Postgate 1982). In nature, diazotrophs are abundant, diverse and exist as free-living state as well as in symbiosis with plants. Many moss species are known to harbor a diverse diazotrophic community (Leppänen et al. 2013; Vile et al. 2014; Knorr et al. 2014; Kox et al. 2016; Weston et al. 2015). The diazotrophic activity associated with Sphagnum supports and explains high concentrations of $\mathrm{N}$ in Sphagnum biomass (Vile et al. 2014). Although it is evident that the mosses benefit from the $\mathrm{N}$ supply by diazotrophs, the benefits for the microorganism are less apparent. Especially, since it was recently postulated that optimal conditions for diazotrophic microorganisms and the moss-host are very different (van den Elzen et al. 2017).

Biological $\mathrm{N}_{2}$ fixation activity is most commonly determined using the acetylene reduction assay (Hardy et al. 1968). Initial studies on the Sphagnum association with $\mathrm{N}_{2}$ fixing partners indicated that mainly cyanobacteria contributed to the incorporation of $\mathrm{N}$ in Sphagnum biomass (Berg et al. 2012; Lindo et al. 2013). Although the acetylene reduction assay is a sensitive and easy way to determine $\mathrm{N}_{2}$ fixing activity, acetylene itself is an irreversible inhibitor of the methane monooxygenase enzyme in methane $\left(\mathrm{CH}_{4}\right)$ oxidizing bacteria (methanotrophs). This prevents methanotrophs from metabolizing carbon, ultimately leading to cell death. Due to the use of acetylene to measure $\mathrm{N}_{2}$ fixation rates, the role of diazotrophic methanotrophs may have been underestimated (Leppänen et al. 2013; Vile et al. 2014). As an alternative method to measure $\mathrm{N}_{2}$ fixation, ${ }^{15} \mathrm{~N}$-nitrogen $\left({ }^{15} \mathrm{~N}-\mathrm{N}_{2}\right)$ stable isotope incorporation can be used. With this method, Vile et al. (2014) showed a significant contribution of $\mathrm{CH}_{4}$ dependent $\mathrm{N}_{2}$ fixation to the Sphagnum N-pool (Vile et al. 2014). Several Sphagnum 16S rRNA gene-based microbiome studies indicated that Alphaproteobacteria were the most abundant $\mathrm{N}_{2}$ fixing bacteria (Bragina et al. 2012, 2014; Shcherbakov et al. 2013; Warren et al. 2017). In addition, diversity studies based on nitrogenase nifH gene also showed that Alphaproteobacteria were highly represented (Bragina et al. 2012; Vile et al. 2014; Kox et al. 2016; Warren et al. 2017). Some of these $\mathrm{N}_{2}$ fixing Alphaproteobacteria were found to be methanotrophs (i.e. type II Methylosinus spp., Methylocystis spp.) as well.

Methanotrophs associated with Sphagnum mosses have been shown to support moss growth by producing carbon dioxide $\left(\mathrm{CO}_{2}\right)$ which is subsequently taken up by Sphagnum, especially under $\mathrm{CO}_{2}$ limiting conditions
(Raghoebarsing et al. 2005; Kip et al. 2010). The methanotrophs are hypothesized to benefit from $\mathrm{O}_{2}$ produced by Sphagnum and by being protected from predators inside Sphagnum's hyaline cells (Kostka et al. 2016). However, activity measurements of methanotrophic diazotrophs in environmental Sphagnum moss samples have yielded contrasting results (Larmola et al. 2014; Leppänen et al. 2014). Due to the high energy demand of $\mathrm{N}_{2}$ fixation, a methanotrophic diazotroph requires high methanotrophic activity in order to sustain $\mathrm{N}_{2}$ fixation. Therefore, parameters controlling methanotrophy supposedly contribute to the observed variability in the $\mathrm{CH}_{4}$ dependent $\mathrm{N}_{2}$ fixation (Ho and Bodelier 2015). To this point, the composition of the active $\mathrm{N}_{2}$ fixing community associated with Sphagnum and factors that affect this activity have been investigated in only a few studies (Ho and Bodelier 2015). The microorganisms involved in biological $\mathrm{N}_{2}$ fixation have been identified, but their relative importance and factors controlling their activity remain unresolved (Ho and Bodelier 2015).

The aim of this study was to elucidate the effect of $\mathrm{O}_{2}$ and $\mathrm{CH}_{4}$ on $\mathrm{N}_{2}$ fixation in Sphagnum mosses of oligotrophic and mesotrophic subarctic Sphagnum-dominated peatlands. Sphagnum mosses were sampled from two mesotrophic and three oligotrophic sites (Lakkasuo peatland in Orivesi, Finland). Sphagnum mosses were incubated under either ambient or low oxygen conditions in the presence or absence of ${ }^{13} \mathrm{C}$-labeled $\mathrm{CH}_{4}$ and ${ }^{15} \mathrm{~N}$-labeled $\mathrm{N}_{2}$. Higher $\mathrm{N}_{2}$ fixation activity is expected for severe nutrient limited conditions (oligotrophic) compared to mesotrophic conditions. On the other hand, more buffered conditions and higher $\mathrm{pH}$ prevailing in mesotrophic peatlands have previously been shown to be beneficial to $\mathrm{N}_{2}$ fixation (van den Elzen et al. 2017). We hypothesize that $\mathrm{CH}_{4}$ will stimulate $\mathrm{N}_{2}$ fixation activity and this activity will be highest in low $\mathrm{O}_{2}$ conditions.

\section{Materials and methods \\ Site description and experimental set-up}

The study was performed in the subarctic, nutrient limited mire complex Lakkasuo in central Finland $\left(61^{\circ} 47^{\prime} \mathrm{N}\right.$ $24^{\circ} 18^{\prime} \mathrm{E}$; 150 m.a.s.l.). Lakkasuo is a well-studied boreal mire complex, with an annual $\mathrm{N}$ input via rainwater of $0.40 \mathrm{~g} \mathrm{~N} \mathrm{~m}^{-2}$ year $^{-1}$ (Laine 2004). Sphagnum mosses were collected in September 2014 from oligotrophic and mesotrophic fens and a rainwater-fed bog within the same peatland basin (Additional file 1: Table S1). The mesotrophic fen site dominated by Sphagnum subsecundum (site A) was a wet fen system, whereas mesotrophic fen site B with Sphagnum obtusum was drier. The oligotrophic fen site was naturally divided in two patches where Sphagnum fallax (site C) and Sphagnum papillosum (site D), respectively, were dominant. The 
rainwater-fed bog site was dominated by Sphagnum majus (site E). See Additional file 1: Table S2 for a full overview of the site vegetation index.

\section{Incubations}

To test whether availability of $\mathrm{O}_{2}$ and/or $\mathrm{CH}_{4}$ would affect microbial $\mathrm{N}_{2}$ fixation rates, Sphagnum mosses were incubated under two different $\mathrm{O}_{2}$ concentrations (ambient and depleted) and with or without ${ }^{13} \mathrm{C}_{-} \mathrm{CH}_{4}$. $\mathrm{N}_{2}$ fixation and $\mathrm{CH}_{4}$ oxidation activity were estimated by measuring the incorporation of ${ }^{15} \mathrm{~N}-\mathrm{N}_{2}$ and ${ }^{13} \mathrm{C}-\mathrm{CH}_{4}$ respectively. To correct for the natural presence of ${ }^{15} \mathrm{~N}$ and ${ }^{13} \mathrm{C}$ in the moss, controls were incubated without any labelled gasses.

Per treatment, moss samples (10 plantlets per bottle, top $3 \mathrm{~cm}$ ) from each site were incubated in $180 \mathrm{ml}$ plastic Scholl flasks and closed with septum containing screw-caps. Before incubation, the fresh weight (FW) of the mosses was determined. All bottles received 5\% ${ }^{15} \mathrm{~N}-\mathrm{N}_{2}$ in the headspace, except for the background controls. ${ }^{13} \mathrm{C}-\mathrm{CH}_{4}$ treated samples received additionally $5 \%$ ${ }^{13} \mathrm{C}-\mathrm{CH}_{4}$ in the headspace. The headspace of the ambient $\mathrm{O}_{2}$ condition consisted of air. Low $\mathrm{O}_{2}$ conditions were achieved by replacing (four cycles of vacuum-helium gassing) the headspace with an artificial gas mixture consisting of $\mathrm{N}_{2}$ gas (80\%), $\mathrm{CO}_{2}(0.04 \%)$ and helium (20\%). Oxygen was not added, so that the only source of oxygen was photosynthesis by the mosses. Samples were incubated for $48 \mathrm{~h}$ outside under prevailing light and temperature conditions (Jyväskylä, Finland, September 2014).

\section{Stable isotope incorporation}

After the incubation, moss samples were stored at $-20{ }^{\circ} \mathrm{C}$. Next, samples were freeze-dried using an Alpha 1-4LD plus (Martin Christ GmbH, Osterode am Harz, Germany) and stored at $-20{ }^{\circ} \mathrm{C}$. Dried stems from each treatment were pooled and disrupted using a beadbeater at $1500 \mathrm{rpm}$ for $3 \mathrm{~min}$ (Microdismembrator U, B. Braun Biotech Int., Meisungen, Germany). To determine the fraction of ${ }^{15} \mathrm{~N}$ and ${ }^{13} \mathrm{C}$ incorporated in plant biomass, approximately 5 and $0.225 \mathrm{mg}$, respectively, were put into $5 \times 8 \mathrm{~mm}$ tin cups in duplo. Next, samples were combusted by flash combustion $\left(1800{ }^{\circ} \mathrm{C}\right)$ on a CNS analyzer (EA 1110 Carlo Erba, Thermo Fisher Scientific, Waltham, MA, USA) coupled to an Isotopic Ratio Mass Spectrometer (Finnigan DeltaPlus, Thermo Electro GmbH, Bremen Germany) via an interface (Conflo III, Thermo Electro $\mathrm{GmbH}$, Bremen, Germany). ${ }^{15} \mathrm{~N}$ and ${ }^{13} \mathrm{C}$ content of all mosses before incubation were uniform.

The ${ }^{15} \mathrm{~N}-\mathrm{N}_{2}$ fixation rates were calculated by correcting the $\delta \mathrm{N}$ of the enriched plant material for the natural ${ }^{15} \mathrm{~N}$ content, after which the corrected ${ }^{15} \mathrm{~N}$ increase was converted to ${ }^{15} \mathrm{~N}-\mathrm{N}_{2}$ fixation rates $\left(\mu \mathrm{mol} \mathrm{N} \mathrm{g}{ }^{-1}\right.$ DW day ${ }^{-1}$ ).
${ }^{13} \mathrm{C}-\mathrm{CH}_{4}$ oxidation rates were calculated in a similar fashion as the ${ }^{15} \mathrm{~N}-\mathrm{N}_{2}$ fixation rates. First, the background ${ }^{13} \mathrm{C}$ label was subtracted from the measured increase in ${ }^{13} \mathrm{C}$ of the biomass. The corrected ${ }^{13} \mathrm{C}$ increase was subsequently converted into ${ }^{13} \mathrm{C}-\mathrm{CH}_{4}$ oxidation rates.

\section{Porewater composition}

At each site $\mathrm{pH}$ was measured and pore water samples were taken using rhizons (pore size $2 \mu \mathrm{m} ; 5 \mathrm{~cm}$ length) at the surface $(0 \mathrm{~cm}), 5,10$ and $15 \mathrm{~cm}$ depth. Element concentrations of $\mathrm{Al}, \mathrm{Ca}, \mathrm{Fe}, \mathrm{K}, \mathrm{Mg}, \mathrm{Mn}, \mathrm{Na}, \mathrm{P}, \mathrm{S}, \mathrm{Si}$ and $\mathrm{Zn}$ in pore water $\left(10 \mathrm{ml}\right.$, acidified with $\left.1 \mathrm{ml} \mathrm{HNO}_{3}\right)$ were analyzed by inductively coupled plasma optical emission spectroscopy (ICP-OES iCAP 6000, Thermo Fisher Scientific, Waltham, MA, USA). Concentrations of $\mathrm{NH}_{4}{ }^{+}$, $\mathrm{NO}_{3}{ }^{-}, \mathrm{PO}_{4}{ }^{3-}$ were analyzed colorimetrically with a 3 Auto Analyzer system (Bran and Luebbe GmbH, Norderstedt, Germany) using ammonium molybdate (Henriksen 1965), hydrazine sulfate (Kamphake et al. 1967) or salicylate (Grasshoff and Johannsen 1972). Cl was determined with a Technicon Flame Photometer IV Control (Bran and Luebbe, Norderstedt, Germany).

To determine the concentration of dissolved methane, $3 \mathrm{ml}$ exetainers (Labco, Ceredigion, UK) were prepared with $1 \mathrm{~g}$ of $\mathrm{NaCl}$ and closed with a septum cap. Next, $1 \mathrm{ml}$ of the porewater collected via rhizons was added to the closed exetainers immediately after sampling. The pressure in the vials was measured and the $\mathrm{CH}_{4}$ concentration in the headspace of the exetainer was measured using the GC as described above.

\section{Olsen-P determination}

Digestion of dried and ground Sphagnum tissue was performed to obtain the Olsen P concentration as described (van den Elzen et al. 2017). In brief, samples were heated to $120{ }^{\circ} \mathrm{C}$ for $45 \mathrm{~min}$ in a mixture of $500 \mu \mathrm{l} \mathrm{HNO}_{3}$ (65\% w/w) with $200 \mu \mathrm{l} \mathrm{H}_{2} \mathrm{O}_{2}(30 \% \mathrm{w} / \mathrm{w})$. Next, samples were diluted with demineralized water and measured by inductively-coupled plasma emission spectrometry (IRIS Intrepid II, Thermo Electron corporation, Franklin, MA, USA).

\section{DNA extraction and 16S rRNA gene amplification}

Sphagnum mosses for molecular analysis were sampled directly from the field and immediately put in liquid nitrogen. In the laboratory, samples were stored at $-80{ }^{\circ} \mathrm{C}$. DNA extraction was performed on $0.5 \mathrm{~g}$ of sample (fresh weight), using the FastDNA SPIN kit for soil (MP Biomedicals, Santa Ana, CA, USA), following manufacturers protocol. Beadbeating was increased to $2 \times 1.5 \mathrm{~min}$ at $50 \mathrm{~Hz}$ using a tissue lyser (LT, Qiagen, Hilden, Germany) DNA yield was assessed using Qubit fluorometric analysis (Thermo Fisher Scientific, 
Waltham, MA, USA). Barcoded 16S rRNA gene amplicon library was prepared with a 2 step PCR protocol (Berry et al. 2011). Used primers targeted the V3-V4 region of the 16S rRNA gene of most bacteria (341F-785R; Klindworth et al. 2013). The $25 \mu \mathrm{l} \mathrm{PCR}$ reactions for the first PCR contained 12.5 $\mu \mathrm{l}$ Quanta perfecta mix (Quantabio, Beverly, MA, USA), $1 \mu \mathrm{l}$ of each primer $(20 \mu \mathrm{M}), 1 \mu \mathrm{l}$ DNA $(0.5 \mathrm{ng} / \mu \mathrm{l})$. The PCR program consisted of 25 cycles of $95^{\circ} \mathrm{C} 1 \mathrm{~min}, 60^{\circ} \mathrm{C}, 1 \mathrm{~min}, 72{ }^{\circ} \mathrm{C}$ for $2 \mathrm{~min}$, after which final elongation $10 \mathrm{~min} 72{ }^{\circ} \mathrm{C}$. The obtained PCR products were checked for purity and size on $1.5 \%$ agarose gel. PCR products of 7 parallel reactions were pooled and purified using QIAquick purification kit (Qiagen, Hilden, Germany) following manufacturers protocol. The second PCR was performed to barcode all samples (bcPCR). For bcPCR the gene-specific The same PCR primers (341F and 785R) as for the first PCR reaction were tagged with adapter sequences, specific barcodes and key sequences at the $5^{\prime}$ end, compatible with Ion Torrent sequencing technology (total 60-62 nucleotides per primer). For each sample six nested bcPCR reactions were conducted in parallel, which were combined after product purity and size control. Subsequently, nested PCR products were purified using QIAquick purification kit (Qiagen, Hilden, Germany) following manufacturers protocol.

\section{Amplicon sequencing}

Prior to Ion torrent library construction, concentration and fragment length of samples was determined with a Bioanalyzer 2100 and the High Sensitivity DNA kit (Agilent Technologies, Santa Clara, CA, USA). The libraries were diluted to a final concentration of $26 \mathrm{pM}$. According to manufacturer's protocol the library fragments were attached to Ion Sphere particles using the One Touch instrument and Ion PGM Template OT2 400 kit (Life Technologies, Carlsbad, CA, USA). Subsequently, Ion Sphere particles were loaded on an Ion 318 v2 Chip for the first run and an Ion 314 v2 chip for the second run, after which the amplicon libraries were sequenced according to manufacturer's protocol using the ION PGM Sequencing 400 Kit, using 850 nucleotide flows. Run 1 (318 chip) resulted in 35,790 reads with an average read length of 132 base pairs. Run 2 resulted in 180,870 reads with an average read length of 275 base pairs.

\section{Sequence analysis}

Sequences from both runs were merged resulting in a total of 216,660 reads with an average length of 252 nucleotides. The reads were analysed using Mothur (v1.38; Schloss et al. 2009) and the Mothur 454 SOP (Schloss et al. 2011). First, reads were quality filtered on read length (200-450 bp) allowing for homopolymers (maximum 8), a maximum of 2 differences with the primer sequence and minimum average quality score of 20 over a window of 50 base pairs. Improved reads were aligned to the Silva nr database (release v123) (Quast et al. 2013). Chimera's were removed using Uchime. Next, reads were classified at bootstrap value of $80 \%$, after which the unwanted and non-target lineages Archaea, Eukaryota, chloroplast, mitochondria and unknown were removed. The final dataset from which OTUs were clustered consisted of 49,975 sequences of which 16,493 were unique, with an average read length of 221 nucleotides (for a detailed overview of quality filtering see Additional file 1: Table S3). OTU's were clustered using the average clustering algorithm at a cut off of 0.03 , followed by singleton removal and resulted in 2001 OTUs. Sequences were deposited in NCBI SRA under project number PRJNA432031.

\section{Statistical analysis}

Data was analyzed using $\mathrm{R}$ version 3.4 .0 by the $\mathrm{R}$ Development Core Team (2017). Normality of the residuals was tested using Shapiro-Wilk's normality test (statspackage). Homogeneity of variance was tested using Levene's test (car-package). In the analysis of $\mathrm{N}_{2}$ fixation, $\mathrm{CH}_{4}$ oxidation activity and pore water composition, the sites were grouped based on their nutritional trophic state, resulting in the levels: mesotrophic and oligotrophic sites. Grouping was only allowed if the difference between species was not significant $(\mathrm{p}>0.05)$, which was tested first using a one-way ANOVA. $\mathrm{N}_{2}$ fixation activity data was transformed by square root transformation to permit parametric tests. Next, differences in $\mathrm{N}_{2}$ fixation activity under the different $\mathrm{O}_{2}$ conditions, presence of ${ }^{13} \mathrm{C}-\mathrm{CH}_{4}$ and sites (oligotrophic or mesotrophic), were tested using a 3-way ANOVA (stats-package; for sample size (n) see Additional file 1: Table $\mathrm{S} 5) .{ }^{13} \mathrm{C}-\mathrm{CH}_{4}$ oxidation activity data was normally distributed. Differences in activity between the two oxygen treatments and sites were tested using a 2-way ANOVA (stats-package). All graphs were constructed in $\mathrm{R}$ using ggplot 2 .

For downstream analysis of the community composition the OTU table and taxonomy files generated by Mothur, were imported into $\mathrm{R}$ and analyzed using phyloseq (McMurdie and Holmes 2013).

\section{Results}

\section{Porewater composition}

The oligotrophic sites were more acidic compared to the mesotrophic sites and contained less dissolved $\mathrm{CH}_{4}$ (see Additional file 1: Figure S1). Concentrations of $\mathrm{NH}_{4}{ }^{+}, \mathrm{NO}_{3}{ }^{-}$and $\mathrm{PO}_{4}^{-}$were lowest in the rainwater fed bog (not shown) and were present in slightly higher concentrations in both oligotrophic and mesotrophic fens. Moreover, both oligotrophic 
and mesotrophic fens showed overall higher elemental concentrations of $\mathrm{S}, \mathrm{Fe} \mathrm{Mg}, \mathrm{K}$ and $\mathrm{Ca}$, compared to the bog. Olsen $\mathrm{P}$ was higher in mosses originating from mesotrophic sites $\left(0.65 \pm 0.02 \mu \mathrm{mol} \mathrm{P} \mathrm{g}^{-1} \mathrm{DW}\right.$, see Additional file 1: Figure S2) than in oligotrophic sites $\left(0.54 \pm 0.01 \mu \mathrm{mol} \mathrm{P} \mathrm{g}{ }^{-1} \mathrm{DW}\right)$.

\section{$\mathrm{N}_{2}$ fixation and $\mathrm{CH}_{4}$ oxidation activity}

$\mathrm{N}_{2}$ fixation rates as measured by ${ }^{15} \mathrm{~N}-\mathrm{N}_{2}$ incorporation were similar in all sites (mesotrophic $1.6 \pm 0.4$ and oligotrophic $1.5 \pm 0.4 \mu \mathrm{mol}{ }^{15} \mathrm{~N}-\mathrm{N}_{2} \mathrm{~g}^{-1} \mathrm{DW}$ day $^{-1}$ ). The $\mathrm{N}_{2}$ fixation rates were not affected by ${ }^{13} \mathrm{C}-\mathrm{CH}_{4}$ addition ( $p>0.05)$, but were affected by absence of $\mathrm{O}_{2}\left(\mathrm{~F}_{1,16}=6.40\right.$ $\mathrm{p}=0.022$; see Fig. 1). Incubation under low $\mathrm{O}_{2}$ conditions yielded higher $\mathrm{N}_{2}$ fixation activity $\left(2.0 \pm 0.5 \mu \mathrm{mol}{ }^{15} \mathrm{~N}-\right.$ $\mathrm{N}_{2} \mathrm{~g}^{-1}$ DW day $^{-1}$ ) compared to incubations at ambient $\mathrm{O}_{2}$ conditions $\left(0.8 \pm 0.2 \mu \mathrm{mol}^{15} \mathrm{~N}-\mathrm{N}_{2} \mathrm{~g}^{-1} \mathrm{DW}\right.$ day $\left.^{-1}\right)$.

$\mathrm{CH}_{4}$ oxidation occurred in all incubations, and ${ }^{13} \mathrm{C}-$ $\mathrm{CH}_{4}$ incorporation was similar ( $\left.\mathrm{p}>0.05\right)$ in all incubations (overall rate $12.0 \pm 1.1 \mu \mathrm{mol}{ }^{13} \mathrm{C}-\mathrm{CH}_{4} \mathrm{~g}^{-1} \mathrm{DW}$ day ${ }^{-1}$ ) (Fig. 2).

\section{Microbial community analysis}

The bacterial community analysis showed that the Proteobacteria were the most dominant phylum in all samples (Fig. 3). In the oligotrophic fen samples Alphaproteobacteria were the most abundant class present ( $>50 \%$ within phylum Proteobacteria; see Fig. 3 and Additional file 1:

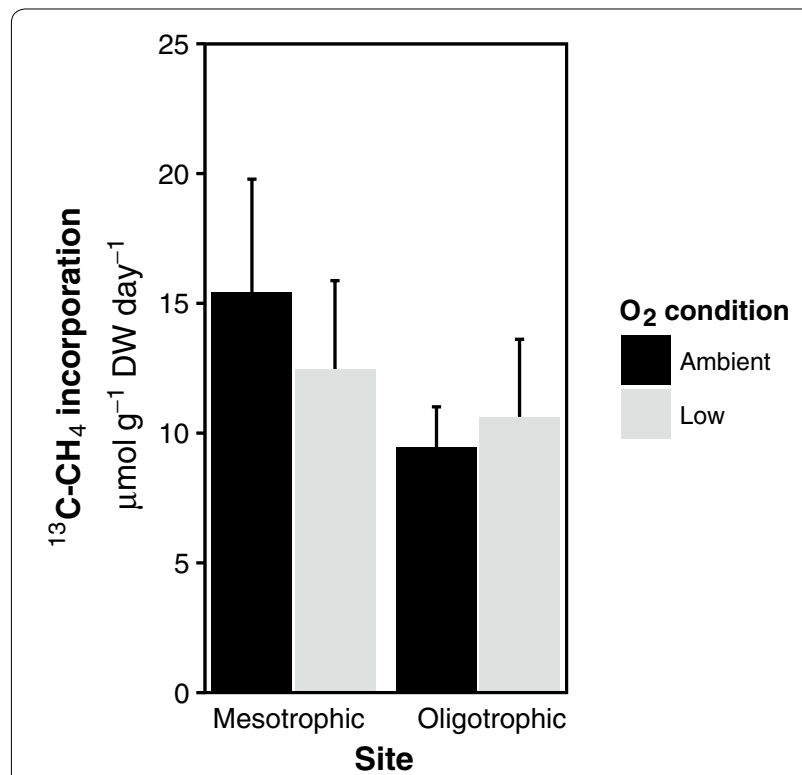

Fig. 2 Incorporation of ${ }^{13} \mathrm{C}_{-} \mathrm{CH}_{4}\left(\mu \mathrm{mol} \mathrm{g}{ }^{-1} \mathrm{DW}\right.$ day $\left.{ }^{-1}\right)$ in Sphagnum mosses from mesotrophic fens and oligotrophic fens and bog sites, incubated with ambient $\mathrm{O}_{2}$ conditions (dark grey bars) or low $\mathrm{O}_{2}$ conditions (light grey bars)

Figure S4). The most abundant families within the Alphaproteobacteria are: Acetobacteraceae and the Caulobacteraceae. The other phyla that made up at least $1 \%$ of

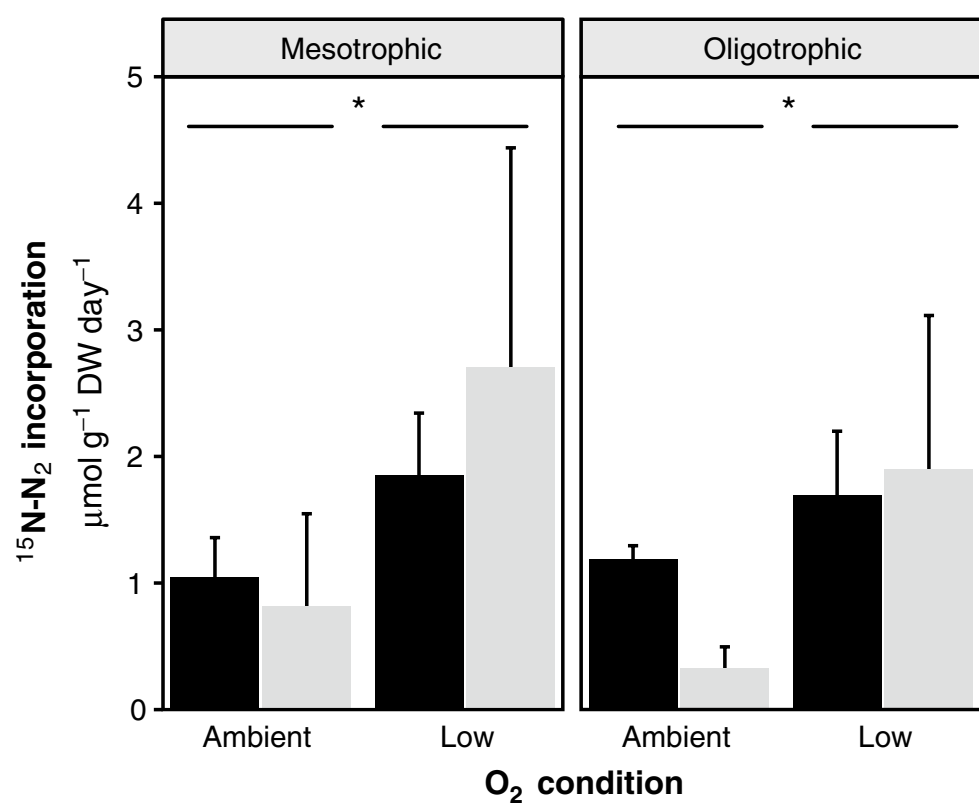

\section{Labelling}

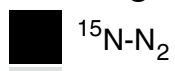

${ }^{15} \mathrm{~N}-\mathrm{N}_{2}+{ }^{13} \mathrm{C}-\mathrm{CH}_{4}$

Fig. 1 Incorporation of ${ }^{15} \mathrm{~N}-\mathrm{N}_{2}\left(\mu \mathrm{mol} \mathrm{g}{ }^{-1} \mathrm{DW}\right.$ day $\left.{ }^{-1}\right)$ in the mesotrophic fens $(\mathrm{n}=2)$ and oligotrophic fens and bog $(\mathrm{n}=3)$ Sphagnum mosses incubated with ambient $\mathrm{O}_{2}$ conditions (dark grey bars) or low $\mathrm{O}_{2}$ conditions (light grey bars), supplemented with $5 \%{ }^{15} \mathrm{~N}-\mathrm{N}_{2}$ (dark grey bars) or $5 \%$ ${ }^{15} \mathrm{~N}-\mathrm{N}_{2}+5 \%{ }^{13} \mathrm{C}-\mathrm{CH}_{4}$ (light grey bars) 


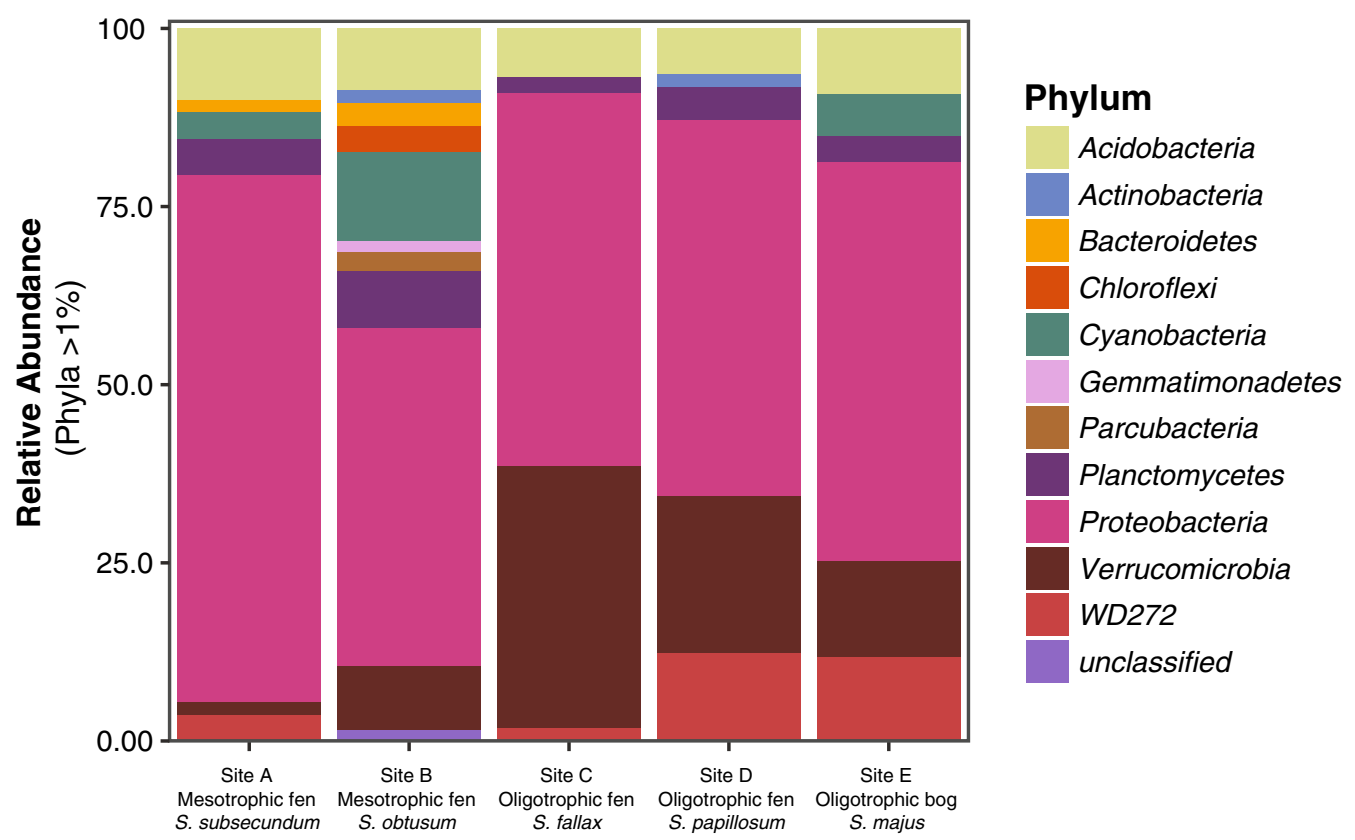

Fig. 3 Taxonomic composition (16S rRNA) of the microbial community associated with Sphagnum moss from site A-E. Bar charts represent the relative abundance of the different phyla present in each site. Only phyla with a RA $>1 \%$ are shown

the microbial community and that appeared to be present in all sites were the Acidobacteria, Verrucomicrobia and the Planctomycetes (Fig. 3). The phylum of Acidobacteria had a comparable relative abundance across all sites. In contrast, the Bacteroidetes and Cyanobacteria were only present in some sites. Genuine methanotrophic proteobacterial 16S rRNA sequences (type I and type II) were less than $0.1 \%$ in relative abundance in all samples.

In the mesotrophic sites, higher microbial diversity was observed (see Additional file 1: Figure S3) compared to the oligotrophic sites. Verrucomicrobia were relatively less abundant in the mesotrophic sites compared to the oligotrophic sites, whereas the Bacteroidetes ( $4 \%$ of total reads) and Cyanobacteria (3\% of total reads) were more abundantly found in the mesotrophic sites.

\section{Discussion}

This study aimed to elucidate the effect of $\mathrm{CH}_{4}$ and $\mathrm{O}_{2}$ availability on $\mathrm{N}_{2}$ fixation activity in oligotrophic and mesotrophic Sphagnum-dominated peatlands. Biological $\mathrm{N}_{2}$ fixation activity was expected to be stimulated by the presence of $\mathrm{CH}_{4}$ and the absence of $\mathrm{O}_{2}$. For the site effect (oligotrophic vs. mesotrophic), expectations were not so clear-cut, as different confounding factors play a role. Higher availability of $\mathrm{N}$ in mesotrophic sites may decrease the demand for biological $\mathrm{N}_{2}$ fixation, while higher $\mathrm{P}$ content may lead to relative $\mathrm{N}$ scarcity. Also, the better buffering and higher $\mathrm{pH}$ of mesotrophic sites may be favorable for $\mathrm{N}_{2}$ fixation.

In the oligotrophic study sites, however, very low concentrations of the $\mathrm{N}$ compounds nitrate and ammonium, typical for oligotrophic conditions, were not found (Additional file 1: Figure S1); they were comparable to concentrations at the mesotrophic sites. Also the N:P relation in porewater was similar, so that no bigger relative $\mathrm{N}$ scarcity could be diagnosed for the oligotrophic site. Only in the biomass, slightly higher Olsen P reflected a generally higher availability of $\mathrm{P}$ in the mesotrophic site. Taken together, this may explain why $\mathrm{N}_{2}$ fixation rates as measured by ${ }^{15} \mathrm{~N}-\mathrm{N}_{2}$ incorporation did not differ between nutritional mesotrophic and oligotrophic trophic states. This is in contrast with recent observations by a study of Van den Elzen et al. (2017), where it was found that $N_{2}$ fixation is stimulated by more buffered conditions and higher phosphorus availability. It is possible that $\mathrm{N}_{2}$ fixation rates in our research were affected by other factors such as the relative dry period in which samples were taken or lack of certain trace elements (Vitousek et al. 2013; Warren et al. 2017).

Methane addition lead to significant uptake of ${ }^{13} \mathrm{C}-$ $\mathrm{CH}_{4}$ derived carbon, but did not affect $\mathrm{N}_{2}$ fixation rates compared to controls, indicating that $\mathrm{CH}_{4}$ dependent $\mathrm{N}_{2}$ fixation is probably not a major contributor to $\mathrm{N}_{2}$ fixation in the studied ecosystem. These results are similar to findings of both Leppänen et al. (2014) and Warren 
et al. (2017). In both studies the addition of methane to batch incubations with Sphagnum did not affect $\mathrm{N}_{2}$ fixation activity either. Furthermore, both studies showed much lower $\mathrm{CH}_{4}$ oxidation activity than observed in the present study, questioning the possibility of an $\mathrm{N}_{2}$-fixing life style of the methanotroph (Ho and Bodelier 2015). Although methanotrophs comprised less than $0.1 \%$ of the $16 \mathrm{~S}$ rRNA, this alone does not exclude them from being a major contributor to $\mathrm{N}_{2}$ fixation. Recently Bae et al. (2018) showed that archaea constituting only $0.27 \%$ of the microbial community could account for $44 \%$ of the $\mathrm{N}$ fixed in an Florida peat system. In addition, $\mathrm{N}_{2}$ fixation rates may differ over seasons (Lett and Michelsen 2014) and thus the microbial guilds actively performing $\mathrm{N}_{2}$ fixation may vary with season. To further confirm which $\mathrm{N}_{2}$ fixing microorganisms are active, transcriptomic studies combined with activity assays over different seasons are required in future studies.

In contrast to $\mathrm{CH}_{4}$ addition, $\mathrm{O}_{2}$ depletion did stimulate $\mathrm{N}_{2}$ fixation. While the mosses in the incubation bottles did produce $\mathrm{O}_{2}$ as they performed oxygenic photosynthesis during the day, the nevertheless lower $\mathrm{O}_{2}$ level resulted in higher $\mathrm{N}_{2}$ fixation rates compared to the ambient $\mathrm{O}_{2}$ levels, which is in line with our hypothesis. The nitrogenase enzyme that is responsible for $\mathrm{N}_{2}$ fixation is irreversibly inhibited by $\mathrm{O}_{2}$ in most microorganisms (Vitousek et al. 2002). Our finding indicates that activity of diazotrophs might be strongly controlled by the oxygen concentration, and therefore by depth, position under or above the water level and the current rate of photosynthesis of Sphagnum. $\mathrm{N}_{2}$ fixation might be higher in the dark than in the light, due to $\mathrm{O}_{2}$ release by Sphagnum during the light period.

The $\mathrm{CH}_{4}$ oxidation rates observed in this study are comparable to $\mathrm{CH}_{4}$ oxidation rates measured in other Sphagnum mosses (Kip et al. 2010). The $\mathrm{CH}_{4}$ oxidation rates were slightly higher in the mesotrophic sites probably due to higher $\mathrm{pH}$. High $\mathrm{CH}_{4}$ oxidation activity is essential for methanotrophs in order to fulfil the high energy required for $\mathrm{N}_{2}$ fixation (Ho and Bodelier 2015). With these high $\mathrm{CH}_{4}$ oxidation rates, energy seems not the limiting factor for $\mathrm{CH}_{4}$ dependent $\mathrm{N}_{2}$ fixation. Taken together it seems highly unlikely that $\mathrm{CH}_{4}$ dependent $\mathrm{N}_{2}$ fixation is a major N-supplier to the N-pool of the Sphagnum mosses investigated in this study.

\section{Microbial community composition}

The observed microbial community composition of the Sphagnum associated microbial community is comparable to the composition found in other studies (Bragina et al. 2012, 2014; Kox et al. 2016) with the Proteobacteria as dominant phylum (Bragina et al. 2011, 2014; Putkinen et al. 2014). The potential to perform $\mathrm{N}_{2}$ fixation has been reported for many phylogenetic groups (Zehr et al. 2003; Dixon and Kahn 2004; Khadem et al. 2010), of which the Alphaproteobacteria, Cyanobacteria, Bacteroidetes and Verrucomicrobia were present in our study. The Alphaproteobacteria which were present in all sites, have previously been identified as potentially important $\mathrm{N}_{2}$ fixing partners of Sphagnum mosses (Bragina et al. 2012; Vile et al. 2014). RT-qPCR and/or transcriptomic sequencing were not performed in this study, therefore we can only speculate which $\mathrm{N}_{2}$ fixers were active.

When we compare the different sites, it is apparent that the oligotrophic fens only contain a limited number of cyanobacterial species, whereas the mesotrophic fens do contain more Cyanobacteria. Potentially the Cyanobacteria may have been affected by the nutrient availability in the peatland, with them becoming more abundant with higher nutrient and productivity levels. The Verrucomicrobial OTU count increased from mesotrophic to the oligotrophic sites, this suggests that species of Verrucomicrobia might thrive better under more oligotrophic conditions (Bragina et al. 2015). The high relative abundance of Verrucomicrobia present in the peat mosses have been found in earlier studies as well (Putkinen et al. 2014; Bragina et al. 2014). Future isolation of Verrucomicrobial species and physiological studies should reveal their metabolic potential with respect to $\mathrm{N}_{2}$ fixation and $\mathrm{CH}_{4}$ oxidation.

Up to this point, factors controlling $\mathrm{N}_{2}$ fixation in Sphagnum mosses have yielded contrasting results. This study has focused on the effect of $\mathrm{O}_{2}$ and $\mathrm{CH}_{4}$ on $\mathrm{N}_{2}$ fixation activity in Sphagnum mosses in oligotrophic and mesotrophic subarctic peatlands. Based upon the results we conclude that $\mathrm{CH}_{4}$ dependent $\mathrm{N}_{2}$ fixation was not a major source of nitrogen for Sphagnum mosses at the studied sites. The microbial community associated with Sphagnum was dominated by Proteobacteria (mainly Alphaproteobacteria), which is comparable to other studies. Future studies should combine field and mesocosm studies, with activity assays, community analysis and transcriptomic data to uncover controls of biological nitrogen fixation in Sphagnum mosses.

\section{Additional file}

Additional file 1. Supplementary tables and figures.

Authors' contributions

MARK, KFE, MSMJ and SLA designed the experiments; MARK, KFE, SLA, and TP sampled the peat mosses and performed the experiments; MARK and MAHJVK analysed the data. The manuscript was written by MARK, MAHJVK and MSMJ.

All co-authors iteratively reviewed the manuscript prior to submission. All authors read and approved the final manuscript.

Author details

${ }^{1}$ Department of Microbiology, Radboud University, Nijmegen, The Netherlands. ${ }^{2}$ Department of Biological and Environmental Science, University 
of Jyväskylä, PO Box 35, 40014 Jyväskylä, Finland. ${ }^{3}$ Department of Environmental and Biological Sciences, University of Eastern Finland, PO Box 1627, 70211 Kuopio, Finland. ${ }^{4}$ Natural Resources Institute Finland, PO Box 2, 00791 Helsinki, Finland.

\section{Acknowledgements}

Marja Tiirola is thanked for feedback on the experiments and manuscript. Jeroen Frank is thanked for setting up bioinformatics pipelines and for useful discussions on 16S rRNA gene diversity analysis.

\section{Competing interests}

The authors declare that they have no competing interests.

\section{Availability of data and materials}

All sequencing data has been deposited in the NCBI SRA database, Project Number PRJNA432031.

\section{Consent for publication}

Not applicable.

\section{Ethics approval and consent to participate}

Not applicable.

\section{Funding}

M.A.R.K. was supported by European Research Council Ecomom 339880 to M.S.M.J., who was further supported by the Netherlands Organisation for Scientific Research (SIAM Gravitation Grant 024002002 and Spinoza Award). K.F.E. was supported by the Netherlands Organisation for Scientific Research (Veni Grant 863.13.007). M.A.H.J.v.K. was supported by Technology Foundation STW (Grant 13146). S.L.A. was supported by Academy of Finland project 260797 and the European Research Council Consolidator project Micro-RIP (615146).

\section{Publisher's Note}

Springer Nature remains neutral with regard to jurisdictional claims in published maps and institutional affiliations.

Received: 24 March 2018 Accepted: 28 April 2018

Published online: 05 May 2018

\section{References}

Bae HS, Morrison E, Chanton JP, Ogram A (2018) Methanogens are major contributors to nitrogen fixation in soils of the Florida Everglades. Appl Environ Microbiol. https://doi.org/10.1128/aem.02222-17

Berg A, Danielsson Å, Svensson BH (2012) Transfer of fixed-N from N2-fixing cyanobacteria associated with the moss Sphagnum riparium results in enhanced growth of the moss. Plant Soil 362:271-278. https://doi. org/10.1007/s11104-012-1278-4

Berry D, Mahfoudh KB, Wagner M, Loy A (2011) Barcoded primers used in multiplex amplicon pyrosequencing bias amplification. Appl Environ Microbiol 77:7846-7849. https://doi.org/10.1128/AEM.05220-11

Bragina A, Berg C, Cardinale M, Shcherbakov A, Chebotar V, Berg G (2011) Sphagnum mosses harbour highly specific bacterial diversity during their whole lifecycle. ISME J 6:1-12. https://doi.org/10.1038/ismej.2011.151

Bragina A, Maier S, Berg C, Müller H, Chobot V, Hadacek F, Berg G (2012) Similar diversity of Alphaproteobacteria and nitrogenase gene amplicons on two related Sphagnum mosses. Front Microbiol 2:1-10. https://doi. org/10.3389/fmicb.2011.00275

Bragina A, Oberauner-Wappis L, Zachow C, Halwachs B, Thallinger GG, Müller H, Berg G (2014) The Sphagnum microbiome supports bog ecosystem functioning under extreme conditions. Mol Ecol. https://doi.org/10.1111/ mec.12885

Bragina A, Berg C, Berg G (2015) The core microbiome bonds the Alpine bog vegetation to a transkingdom metacommunity. Mol Ecol 24:4795-4807. https://doi.org/10.1111/mec.13342

Clymo RS (1963) lon exchange in Sphagnum and its relation to bog ecology. Ann Bot 27:309-324. https://doi.org/10.1093/oxfordjournals.aob.a083847
Clymo RS (1964) The origin of acidity in Sphagnum bogs. Bryologist 67:427. https://doi.org/10.2307/3240768

Dixon R, Kahn D (2004) Genetic regulation of biological nitrogen fixation. Nat Rev Microbiol 2:621-631. https://doi.org/10.1038/nrmicro954

Fritz C, Lamers LPM, Riaz M, van den Berg LLL, Elzenga TJTM (2014) Sphagnum mosses - masters of efficient N-uptake while avoiding intoxication. PLoS ONE 9:1-11. https://doi.org/10.1371/journal.pone.0079991

Gorham E (1991) Northern peatlands: role in the carbon cycle and probable responses to climatic warming. Ecol Appl 1:182-195

Grasshof K, Johannse H (1972) New sensitive and direct method for automatic determination of ammonia in seawater. J Cons 34:516-521

Hardy RW, Holsten RD, Jackson EK, Burns RC (1968) The acetylene-ethylene assay for $\mathrm{N}_{2}$ fixation: laboratory and field evaluation. Plant Physiol 43:1185-1207

Henriksen A (1965) An automated method for determining low-level concentrations of phosphate in fresh and saline waters. Analyst 90:29-34

Ho A, Bodelier PL (2015) Diazotrophic methanotrophs in peatlands: the missing link? Plant Soil 389:185-196. https://doi.org/10.1007/ s11104-015-2393-9

Kamphake LJ, Hannah SA, Cohen JM (1967) Automated analysis for nitrate by hydrazine reduction. Water Res 1:205-216

Khadem AF, Pol A, Jetten MSM, den Camp HJMO (2010) Nitrogen fixation by the verrucomicrobial methanotroph "Methylacidiphilum fumariolicum"SolV. Microbiology 156:1052-1059

Kip N, van Winden JF, Pan Y, Bodrossy L, Reichart GJ, Smolders AJP, Jetten MSM, Damsté JSS, den Camp HJMO (2010) Global prevalence of methane oxidation by symbiotic bacteria in peat-moss ecosystems. Nat Geosci 3:617-621

Klindworth A, Pruesse E, Schweer T, Peplies J, Quast C, Horn M, Glöckner FO (2013) Evaluation of general 165 ribosomal RNA gene PCR primers for classical and next-generation sequencing-based diversity studies. Nucleic Acids Res 41:1-11. https://doi.org/10.1093/nar/gks808

Knorr KH, Horn MA, Borken W (2014) Significant non-symbiotic nitrogen fixation in Patagonian ombrotrophic bogs. Glob Change Biol. https://doi. org/10.1111/gcb.12849

Kostka JE, Weston DJ, Glass JB, Lilleskov EA, Shaw AJ, Turetsky MR (2016) The Sphagnum microbiome: new insights from an ancient plant lineage. New Phytol 211:57-64. https://doi.org/10.1111/nph.13993

Kox MAR, Lüke C, Fritz C, van den Elzen E, Alen T, Op den Camp HJM, Lamers LPM, Jetten MSM, Ettwig KF (2016) Effects of nitrogen fertilization on diazotrophic activity of microorganisms associated with Sphagnum magellanicum. Plant Soil 406:83-100. https://doi.org/10.1007/ s11104-016-2851-z

Laine J (2004) Lakkasuo: a guide to mire ecosystem. Metsäekologian Laitos, Helsinki

Larmola T, Leppänen SM, Tuittila ES, Aarva M, Merilä P, Fritze H, Tiirola M (2014) Methanotrophy induces nitrogen fixation during peatland development. Proc Natl Acad Sci USA 111:734-739. https://doi.org/10.1073/ pnas. 1314284111

Leppänen SM, Salemaa M, Smolander A, Mäkipää R, Tiirola M (2013) Nitrogen fixation and methanotrophy in forest mosses along a $\mathrm{N}$ deposition gradient. Environ Exp Bot 90:62-69. https://doi.org/10.1016/j. envexpbot.2012.12.006

Leppänen SM, Rissanen AJ, Tiirola M (2014) Nitrogen fixation in Sphagnum mosses is affected by moss species and water table level. Plant Soil. https://doi.org/10.1007/s11104-014-2356-6

Lett S, Michelsen A (2014) Seasonal variation in nitrogen fixation and effects of climate change in a subarctic heath. Plant Soil 379:193-204. https://doi. org/10.1007/s11104-014-2031-y

Lindo Z, Nilsson MC, Gundale MJ (2013) Bryophyte-cyanobacteria associations as regulators of the northern latitude carbon balance in response to global change. Glob Change Biol 19:2022-2035. https://doi.org/10.1111/ gcb. 12175

Malmer N, Albinsson C, Svensson BM, Wallén B (2003) Interferences between Sphagnum and vascular plants: effects on plant community structure and peat formation. Oikos 100:469-482

McMurdie PJ, Holmes S (2013) Phyloseq: an R package for reproducible interactive analysis and graphics of microbiome census data. PLOS ONE. https://doi.org/10.1371/journal.pone.0061217

Postgate JR (1982) Biology nitrogen fixation: fundamentals. Philos Trans R Soc B Biol Sci 296:375-385 
Putkinen A, Larmola T, Tuomivirta T, Siljanen HMP, Bodrossy L, Tuittila ES, Fritze $H$ (2014) Peatland succession induces a shift in the community composition of Sphagnum-associated active methanotrophs. FEMS Microbiol Ecol 88:596-611. https://doi.org/10.1111/1574-6941.12327

Quast C, Pruesse E, Yilmaz P, Gerken J, Schweer T, Yarza P, Peplies J, Glöckner FO (2013) The SILVA ribosomal RNA gene database project: improved data processing and web-based tools. Nucleic Acids Res 41:590-596. https:// doi.org/10.1093/nar/gks1219

R Development Core Team (2017) R: a language and environment for statistical computing. R Foundation for Statistical Computing, Vienna

Raghoebarsing AA, Smolders AJP, Schmid MC, Rijpstra WIC, Wolters-Arts M, Derksen J, Jetten MSM, Schouten S, Damsté JSS, Lamers LPM, Roelofs JGM, den Camp HJMO, Strous M (2005) Methanotrophic symbionts provide carbon for photosynthesis in peat bogs. Nature 436:1153-1156. https://doi.org/10.1038/nature03802

Schloss PD, Westcott SL, Ryabin T, Hall JR, Hartmann M, Hollister EB, Lesniewski RA, Oakley BB, Parks DH, Robinson CJ, Sahl JW, Stres B, Thallinger GG, Van Horn DJ, Weber CF (2009) Introducing mothur: open-source, platformindependent, community-supported software for describing and comparing microbial communities. Appl Environ Microbiol 75:7537-7541. https://doi.org/10.1128/AEM.01541-09

Schloss PD, Gevers D, Westcott SL (2011) Reducing the effects of PCR amplification and sequencing artifacts on 16s rRNA-based studies. PLOS ONE. https://doi.org/10.1371/journal.pone.0027310

Shcherbakov AV, Bragina AV, Kuzmina EY, Berg C, Muntyan AN, Makarova NM, Malfanova NV, Cardinale M, Berg G, Chebotar VK, Tikhonovich IA (2013) Endophytic bacteria of Sphagnum mosses as promising objects of agricultural microbiology. Microbiology 82:306-315. https://doi.org/10.1134/ S0026261713030107

van Breemen N (1995) How Sphagnum bogs down other plants. Trends Ecol Evol 10:270-275. https://doi.org/10.1016/0169-5347(95)90007-1 van den Elzen E, Kox MAR, Harpenslager SF, Hensgens G, Fritz C, Jetten MSM, Ettwig KF, Lamers LPM (2017) Symbiosis revisited: phosphorus and acid buffering stimulate $\mathrm{N}_{2}$ fixation but not Sphagnum growth. Biogeosciences 14:1111-1122. https://doi.org/10.5194/bg-14-1111-2017

van der Heijden MG, Bardgett RD, van Straalen NM (2008) The unseen majority: soil microbes as drivers of plant diversity and productivity in terrestrial ecosystems. Ecol Lett 11:296-310. https://doi. org/10.1111/j.1461-0248.2007.01139.x

Vile MA, Wieder RK, Živković T, Scott KD, Vitt DH, Hartsock JA, losue CL, Quinn JC, Petix M, Fillingim HM, Popma JM (2014) $\mathrm{N}_{2}$-fixation by methanotrophs sustains carbon and nitrogen accumulation in pristine peatlands. Biogeochemistry 121:317-328. https://doi.org/10.1007/s10533-014-0019-6

Vitousek P, Cassman K, Cleveland C (2002) Towards an ecological understanding of biological nitrogen fixation. Biogeochemistry 57(58):1-45

Vitousek PM, Menge DNL, Reed SC, Cleveland CC (2013) Biological nitrogen fixation: rates, patterns and ecological controls in terrestrial ecosystems. Philos Trans R Soc Lond B Biol Sci 368:20130119. https://doi.org/10.1098/ rstb.2013.0119

Warren MJ, Lin X, Gaby JC, Kretz CB, Kolton M, Morton PL, Pett-Ridge J, Weston DJ, Schadt CW, Kostka JE, Glass JB (2017) Molybdenum-based diazotrophy in a Sphagnum peatland in northern Minnesota. Appl Environ Microbiol. https://doi.org/10.1128/aem.01174-17

Weston DJ, Timm CM, Walker AP, Gu L, Muchero W, Schmutz J, Shaw AJ, Tuskan GA, Warren JM, Wullschleger SD (2015) Sphagnum physiology in the context of changing climate: emergent influences of genomics, modelling and host-microbiome interactions on understanding ecosystem function. Plant Cell Environ 38:1737-1751. https://doi.org/10.1111/pce.12458

Zehr JP, Jenkins BD, Short SM, Steward GF (2003) Nitrogenase gene diversity and microbial community structure: a cross-system comparison. Environ Microbiol 5:539-554

\section{Submit your manuscript to a SpringerOpen ${ }^{\odot}$ journal and benefit from:}

- Convenient online submission

- Rigorous peer review

- Open access: articles freely available online

- High visibility within the field

- Retaining the copyright to your article

Submit your next manuscript at $\boldsymbol{\nabla}$ springeropen.com 